\title{
DISPERSAL AND EXTRATERRITORIAL MOVEMENTS OF SWIFT FOXES (VULPES VELOX) IN NORTHWESTERN TEXAS
}

\author{
Kerry L. Nicholson ${ }^{1,3}$, Warren B. Ballard ${ }^{1,5}$, Brady K. McGee ${ }^{1,4}$, \\ and Heather A. Whitlaw ${ }^{2}$
}

\begin{abstract}
Dispersal plays an important role in the population dynamics of many carnivores, yet little information exists about the dispersal and movement patterns of swift foxes (Vulpes velox). We radio-collared and monitored 68 swift foxes for dispersal at 2 study sites in northwestern Texas from January 2002 to April 2004. Dispersal distance for juveniles $(13.1 \pm 0.3 \mathrm{~km}, s)$, adults $(10 \pm 4.7 \mathrm{~km})$ and transients $(25.4 \pm 9.1 \mathrm{~km})$ did not differ by age class $(F=1.49, \mathrm{df}=2, P$ $=0.24)$ or $\operatorname{sex}(F=0.23 \mathrm{df}=1, P=0.63)$ but differed by study site $(F=4.72 \mathrm{df}=1, P=0.04)$. Mean dispersal distance from private ranches (PR) was greater than from National Grasslands (NG). Peak dispersal occurred during October-November (13 individuals) and January-February (7 individuals). Dispersal direction was influenced by land-use practices (i.e., toward rangelands and away from anthropogenic features). Direction of dispersal among foxes that occupied the NG was uniform $(n=16, P=0.08)$, whereas foxes from PR dispersed in a northwesterly direction $(n=18, P \leq$ 0.001 ) away from a town and croplands. Three resident adult foxes made extraterritorial movements. Distances of these movements ranged from $0.2 \mathrm{~km}$ to $11.4 \mathrm{~km}$. Distance of extraterritorial movements did not differ by sex $(F=0.05, P=$ $0.83)$, nor by duration of movement $(F=1.11, P=0.32)$. Knowledge of movement distances and patterns is important for conservation and protection of swift foxes and their habitats.
\end{abstract}

Key words: swift fox, dispersal, extraterritorial movement.

Persistence of small isolated animal populations depends, in part, on their members' abilities to disperse (Brooker et al. 1999). Landuse practices that alter the landscape may interact or interfere with dispersal capabilities (Keitt et al. 1997). In fragmented landscapes, species that disperse over long distances will perceive a given habitat distribution as more connected than a species with short-range dispersal (Keitt et al. 1997). Landscape pattern can influence movement of species with varying degrees of magnitude. For example, those species that are more adaptable could potentially disperse greater distances and occupy more varied landscapes than those that are rigid in their requirements. Some have suggested that a mechanism must exist, either behavioral or evolutionary, that influences an animal to disperse among habitat patches in a disconnected landscape (Keitt et al. 1997).

Individual foxes sometimes make short-term excursions (hereafter called extraterritorial movements) outside of their established home ranges (Lidicker and Stenseth 1992). Many studies refer to this behavior as an extraterritorial movement. Extraterritorial movements have been documented for many species including wolverines (Gulo gulo), ferrets (Mustela nigripes), hyenas (Crocuta crocuta), meerkats (Suricata suricatta; Doolan and MacDonald 1996), dingoes (Canis familiaris dingo; Thomson et al. 1992), and wolves (Canis lupus; Van Ballenberghe 1983, Ballard et al. 1997). Extraterritorial movements are common among canid species, yet the nature and extent of these movements have been poorly documented (Van Ballenberghe 1983). In a study of wolves, Ballard et al. (1997) defined an extraterritorial movement as an individual temporarily leaving its territory for varying time periods and distances, and then returning to its original territory. These exploratory movements can be motivated by the need to search for a mate or to locate additional resources, better forage, or better living conditions. These excursions might also be a prelude to dispersal and occur commonly among younger age classes (usually juveniles).

\footnotetext{
1Department of Range, Wildlife, and Fisheries Management, Texas Tech University, Box 42125, Lubbock, TX 79409.

${ }^{2}$ Texas Parks and Wildlife Department, Texas Tech University, Box 42125, Lubbock, TX 79409.

${ }^{3}$ Present address: School of Renewable Natural Resources, University of Arizona, 325 Biological Sciences East, Tucson, AZ 85721.

${ }_{4}^{4}$ Present address: Lower Rio Grande Valley National Wildlife Refuge, Route 2, Box 202-A, Alamo, TX 78516.

${ }^{5}$ Corresponding author. E-mail: warren.ballard@ttu.edu
} 


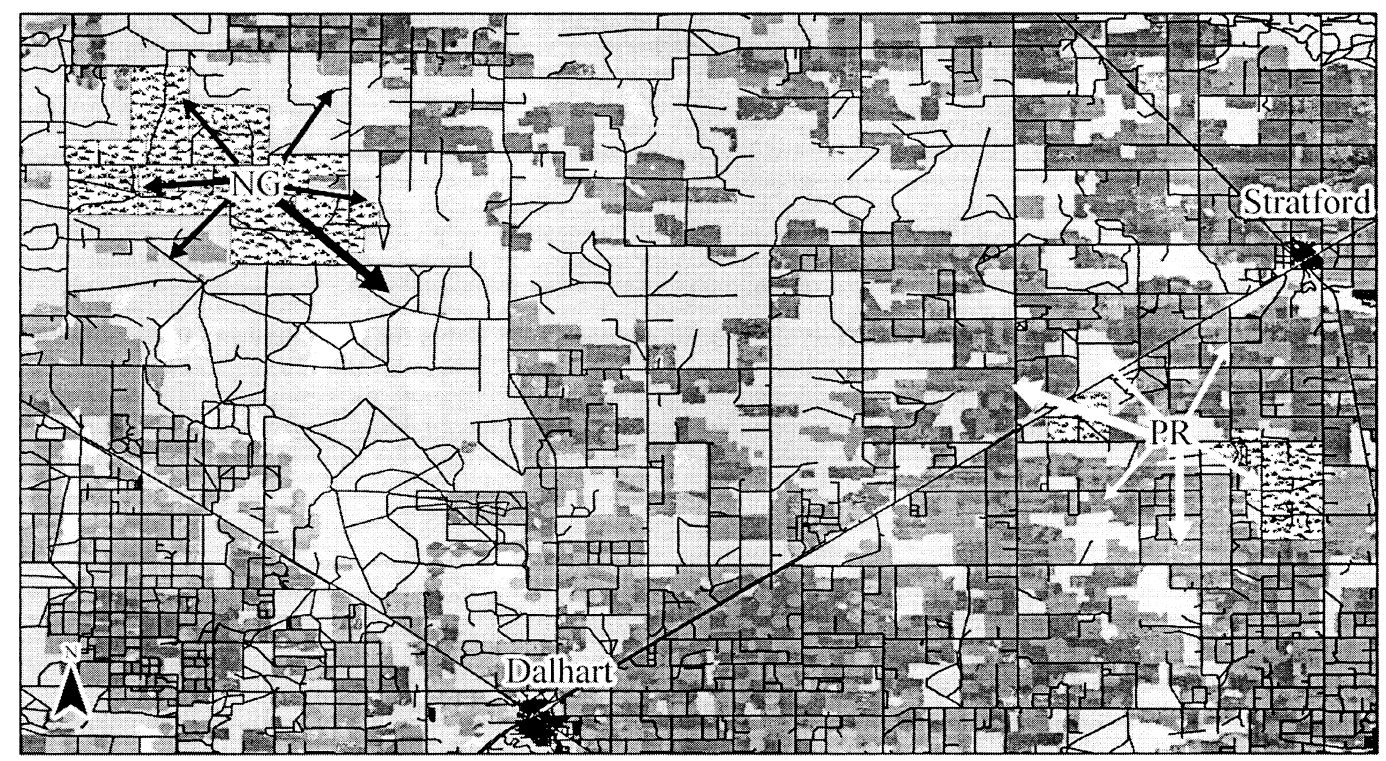

Land Use

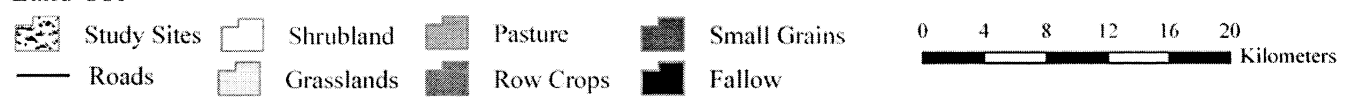

Fig. 1. Land-use map (1992) of Dallam County, Texas, including National Grasslands (NG) and Private Ranch (PR) study sites with swift fox dispersal directions from each study site, 2002-2004. The 2 largest arrows indicate our predicted directions of dispersal.

Few studies have focused primarily on dispersal and extraterritorial movements in swift foxes (Kamler et al. 2004a). Our objectives were to document and evaluate dispersal distances and directions of swift fox movements in fragmented and nonfragmented landscapes of northwestern Texas. We investigated dispersal distances of juvenile swift foxes and compared these distances to those traveled by resident and transient adult dispersers. We also determined survival rates of dispersing swift foxes. While monitoring swift foxes for dispersal we documented occasions of extraterritorial movements in adult swift foxes.

\section{STUdy AREA}

We conducted our research on two $100-\mathrm{km}^{2}$ study sites in northwestern Texas (Fig.1). Our Sherman County study area was on a private ranch $(\mathrm{PR})$ located approximately $12 \mathrm{~km}$ south of Stratford, Texas $\left(36^{\circ} 24^{\prime} \mathrm{N}, 102^{\circ} 19^{\prime} \mathrm{W}\right)$. The PR bordered Dallam County to the west and was surrounded by other ranches, Conservation Reserve Program (CRP) fields, and agri- cultural fields (Fig. 1). The PR consisted of rangelands, CRP lands, and cultivated fields; however, the PR was not a continuous tract of land. There was $3.5 \mathrm{~km}$ of land separating the 2 main sections of land. The 2 nd study site was entirely native rangeland and included parts of the Rita Bianca National Grassland (NG) and private lands in Dallam County, Texas, approximately $55 \mathrm{~km}$ west of Stratford, Texas $\left(36^{\circ} 3^{\prime} \mathrm{N}, 102^{\circ} 64^{\prime} \mathrm{W}\right)$. The National Grasslands were continuous tracts of land only divided by dirt roads (Fig. 1). Refer to Kamler et al. (2002) for a more detailed description of the study area.

\section{Methods}

\section{Capture and Handling}

We captured and processed swift foxes from January 2002 to April 2004 with methods described by Kamler et al. (2002). Trapping occurred throughout both study sites and traps were placed opportunistically near active dens or where unmarked foxes were sighted. There were no mortalities associated with capture. 
We did not trap between April and mid-June to avoid prolonged separation of mothers from their pups.

We recorded sex, age class, weight, and capture location for each fox. We also eartagged each swift fox with a unique identification number. We classified swift foxes as adults $(>6$ months old) or juveniles (young of the year). Age classes were based on morphological characteristics such as size, weight, and tooth wear at the time of capture. We placed radiocollars (40 g; Advanced Telemetry Systems, Inc., Isanti, MN) on swift foxes $>6$ months old. We monitored all animals until they recovered from sedation (Kamler et al. 2002).

\section{Radiotelemetry}

We radio-tracked collared foxes from January 2002 through July 2004. Throughout the study period, we obtained independent telemetry locations for each animal at least every other night during 1700-0700 hours when swift foxes are most active (Kilgore 1969). At least once per week foxes were tracked in the day to their dens. We considered locations independent if they were $>3$ hours apart. All radiotracking was performed by a single observer with a vehicle-mounted, null-peak, 2,4-element Yagi antenna system. To prevent biased locations we began each radio-tracking session by finding a randomly chosen individual. Dispersing and lost foxes were relocated via aerial telemetry from a fixed-wing Cessna 173 (Cessna Aircraft Co., Wichita, KS). Radio-collars had an estimated 9-month lifespan; therefore, foxes that dispersed off the study site, or those that we were unable to recapture, were monitored from aircraft until May of the spring following capture.

We determined animal locations from azimuth angles of $40^{\circ}-140^{\circ}$, made from readings ( $\leq 5$ minutes between each location) from 3 or 4 telemetry locations (White and Garrott 1990). We calculated foxes' locations or point estimates using the maximum likelihood estimator in LOAS (location of a signal; Ecological Software Solutions, Sacramento, CA). Telemetry errors were based on readings of test collars placed in 30 different locations (White and Garrott 1990). Mean error was $47.4 \mathrm{~m}$ or $9^{\circ}$ for known locations of reference collars. Locations of test collars were verified with a Garmin 72 geographic positioning system (GPS) unit (Garmin International, Inc., Olathe, KS).
We tracked swift foxes to their diurnal resting sites (dens) using a handheld antenna 1-2 times per week. We recorded Universal Transverse Mercator (UTM) locations for each den with a GPS unit to assign grid coordinates (accuracy $\leq 5 \mathrm{~m})$.

\section{Dispersal}

We used a $Z$ test to compare dispersal rates between adults and juveniles. For dispersal analyses we defined residents as adults that (1) stayed in 1 area for about 1 year and (2) had a mate. Transients were adult foxes that were never observed with another fox and did not maintain a long-term continuous range. Transients were individuals who did not originate at our site, but rather moved through our study site, though they stayed long enough to be captured and relocated several times before moving off our study site. We classified juveniles as young of the year. Swift foxes tend to have circular home ranges (Kitchen et al. 1999, Kamler 2002), and Karki (2003) reported mean seasonal home ranges of $<6 \mathrm{~km}^{2}$ for adult foxes in Colorado. Koopman et al. (2000) defined dispersal for kit foxes (Vulpes macrotis) as movements $>1.65 \mathrm{~km}$ from the natal range. Therefore, we classified fox movement $\geq 2 \mathrm{~km}$ from the center of home ranges as dispersal if individuals did not return or overlap their original home range (Kamler et al. 2004). We used the standard of Koopman et al. (2000) to calculate date of dispersal as the median of the date of the last location within the home range and the 1st location $>2 \mathrm{~km}$ from the home range. Home ranges of juveniles, or natal range, encompassed all den locations of parents and, if parents were unknown, we used the initial capture locations as the center of the natal range (Koopman et al. 2000). For resident adult dispersing foxes, we calculated dispersal distance as the length between the center of the original home range and the farthest known location before contact was lost. For transients we used the initial capture locations and all relocations for each individual as the center of its range. In some instances there were $<30$ locations for a transient's known range on our study site. We suspect these individuals were attempting to find permanent residence and were unsuccessful within our study boundary. To avoid seasonal shifts confounding our results, we defined dispersing foxes such that the area they occupied before movement did 
not overlap with the area they occupied after movement. We used an analysis of variance (PROC GLM: dispersal distance $=$ age $*$ sex $*$ location) and Tukey's post hoc analysis to assess the difference in dispersal distances of foxes.

We classified dispersal direction (direction of recovery from last known location) as northwest $\left(210^{\circ}-359^{\circ}\right)$, northeast $\left(0^{\circ}-90^{\circ}\right)$, southeast $\left(91^{\circ}-180^{\circ}\right)$, or southwest $\left(181^{\circ}-209^{\circ}\right)$. Angles of specified dispersal were chosen based on direction to the largest section of continuous rangeland from the center of each study site. We tested uniformity in dispersal direction using a Hodges-Ajne test for uniformity and a Batschelet test for uniformity versus a specified angle (Zar 1999). The PR had the largest rangeland available between $270^{\circ}$ and $0^{\circ}$, so we used the northwesterly direction toward $315^{\circ}$; for NG we used the same criteria and chose the southeasterly direction toward $135^{\circ}$. We used SAS 8.02 (SAS Institute, Inc., Cary, $\mathrm{NC})$ for all other statistical analyses and significance was determined at $\alpha=0.05$.

\section{Extraterritorial Movement}

To determine if swift foxes showed signs of extraterritorial movement, we first used the Animal Movement Extension (Hooge et al. 1999) in ArcView 3.2 (Environmental Systems Research Institute, Inc., Redlands, CA) to calculate a $95 \%$ kernel home range for resident and juvenile swift foxes. Each fox had $\geq 35$ locations and we only considered movements beyond the $95 \%$ kernel as possible extraterritorial movements. To be conservative in identifying movements for these analyses, we only used movements that were $\geq 2 \mathrm{~km}$ with a return. We used a 1-way ANOVA to compare distances (distance $=\mathrm{sex}$ ) and duration (duration $=$ sex $)$ of movements between sexes. Sample sizes were too small to compare between study sites. Minimum straight-line distance was measured from the farthest movement location to the closest home range boundary defined by the $95 \%$ kernel estimate. The number of days was counted from the 1st movement location outside the home range to the next location within the home range.

\section{Results}

From January 2002 to April 2004, we radiocollared 68 swift foxes (43 adults, 25 juveniles)
TABLE 1. Average dispersal distances of juvenile, transient, and adult swift foxes in northwestern Texas, 2002-2004.

\begin{tabular}{lccc}
\hline \multirow{2}{*}{ Status } & & \multicolumn{2}{c}{ Dispersal distance $(\mathrm{km})$} \\
\cline { 3 - 4 } & $n$ & $\bar{x} \pm s$ & Range \\
\hline Juvenile & 18 & $19.5 \pm 18.7$ & $2.5-63.5$ \\
Transient & 10 & $29.4 \pm 24.2$ & $2.1-61.0$ \\
Resident & 5 & $34.0 \pm 26.5$ & $7.7-67.7$ \\
\hline
\end{tabular}

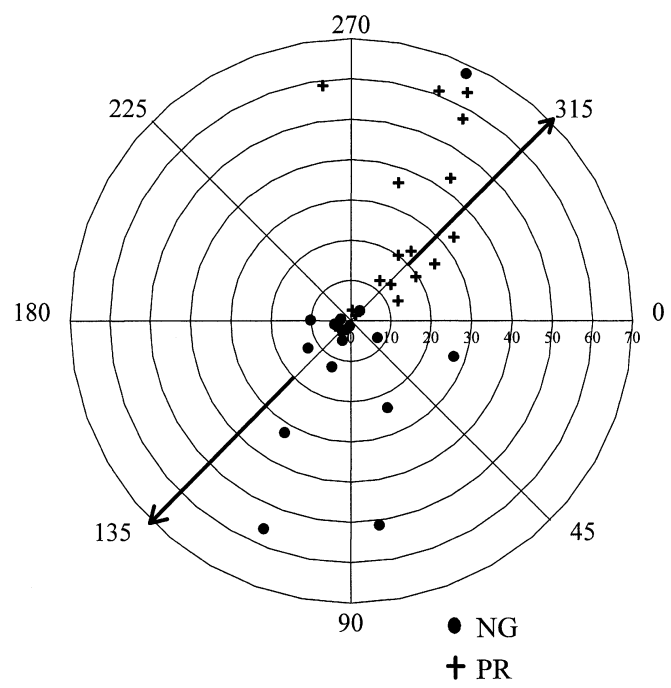

Fig. 2. Direction and distance of swift fox dispersal on the National Grasslands (NG) and Private Ranch (PR) study sites, 2002-2004. Arrows indicate the predicted directions tested.

for dispersal and monitored these foxes through the dispersal period. Eighteen of 25 juveniles dispersed and survived until the end of May; 4 died before dispersal characteristics could be determined; and we eventually lost radio contact with 3 foxes. Adults were either transients or were residents that stayed on the study site, though they still moved without return (Table 1). Juveniles had higher dispersal rates $(86 \%)$ than adults $(8 \% ; Z=4.39, P \leq 0.001)$.

Dispersal distances did not differ by age class $(F=1.49, \mathrm{df}=2, P=0.24)$ or $\operatorname{sex}(F=$ 0.23 , df $=1, P=0.63)$. However, dispersal distances differed by study site $(F=4.72, \mathrm{df}=$ $1, P=0.04)$. Swift foxes on the PR dispersed greater distances than those on the NG (Table 2). Peak dispersal occurred during October- 
TABLE 2. Average dispersal distances of juvenile, transient, and resident adult swift foxes on National Grasslands (NG) and on private ranches (PR) in northwestern Texas, 2002-2004.

\begin{tabular}{llrrr}
\hline \multirow{2}{*}{ Location } & & \multicolumn{2}{c}{ Dispersal distance $(\mathrm{km})$} \\
\cline { 4 - 5 } NG & Status & $n$ & $\bar{x} \pm s$ & Range \\
& Juvenile & 7 & $9.3 \pm 8.7$ & $2.5-27.1$ \\
\multirow{2}{*}{ TotaL } & Transient & 6 & $25.4 \pm 22.2$ & $3.3-54.4$ \\
PR & Resident & 3 & $43.8 \pm 31.8$ & $7.7-67.8$ \\
& & 16 & $21.8 \pm 22.5$ & $2.5-67.8$ \\
\multirow{2}{*}{ TotaL } & Juvenile & 11 & $25.9 \pm 20.8$ & $2.6-63.5$ \\
\hline
\end{tabular}

TABLE 3. Summary of swift fox extraterritorial movements in northwestern Texas, 2002-2004. NG = National Grasslands, $\mathrm{PR}=$ private ranches, $\mathrm{F}=$ female, $\mathrm{M}=$ male.

\begin{tabular}{|c|c|c|c|c|c|}
\hline Foxes & Movements & $\begin{array}{c}\text { Total duration } \\
\text { (days) }\end{array}$ & $\begin{array}{c}\text { Movements } \\
>2 \mathrm{~km}\end{array}$ & $\begin{array}{c}\text { Duration } \\
>2 \mathrm{~km} \text { (days) }\end{array}$ & $\begin{array}{c}\text { Greatest } \\
\text { distance }(\mathrm{km})\end{array}$ \\
\hline NGF 254 & 1 & 1 & 0 & 0 & 0.20 \\
\hline NGF 266 & 4 & 8 & 2 & 2 & 3.41 \\
\hline NGF 277 & 1 & 19 & 1 & 6 & 8.94 \\
\hline NGM 078 & 4 & 22 & 1 & 2 & 3.98 \\
\hline NGM 090 & 5 & 23 & 0 & 0 & 0.39 \\
\hline NGM 249 & 5 & 23 & 2 & 10 & 9.20 \\
\hline NGM 270 & 19 & 44 & 18 & 41 & 4.20 \\
\hline NGM 271 & 2 & 12 & 2 & 12 & 5.00 \\
\hline NGM 276 & 12 & 104 & 3 & 33 & 11.39 \\
\hline PRF 040 & 12 & 28 & 1 & 3 & 7.22 \\
\hline PRF 095 & 7 & 28 & 1 & 1 & 8.73 \\
\hline PRM 099 & 12 & 41 & 4 & 28 & 11.43 \\
\hline PRM 224 & 1 & 1 & 0 & 0 & 1.71 \\
\hline
\end{tabular}

November ( $n=13$ foxes), with a 2 nd dispersal pulse in January-February $(n=7$ foxes).

We determined the dispersal direction of 35 foxes (16 from NG, 18 from PR). Direction was not uniform for all foxes $\left(\mathrm{C}_{0.05}(2), 34=8\right.$, $P=0.03)$, so we tested a specified direction of dispersal based on fragmented or continuous landscapes (NG 135 ${ }^{\circ}$ PR $315^{\circ}$; Fig. 2) for each study site. Dispersal directions for foxes from $\mathrm{NG}$ were not directional $\left(\mathrm{C}_{0.05}(2), 16=4, P=\right.$ 0.08), whereas foxes from $P R$ moved directionally toward $315^{\circ}\left(\mathrm{C}_{0.05}(2), 18=1, \mathrm{P} \leq 0.001\right)$. Dispersal directions for all foxes were northeast (10\% NG, 7\% PR), southeast (28\% NG, $7 \%$ PR), southwest (7\% NG, 3\% PR) and northwest (7\% NG, 31\% PR). Swift foxes dispersed towards rangelands at greater frequencies than towards other land types (Fig. 1).

We monitored 13 resident adults, only 3 of which had movements $<2 \mathrm{~km}$ outside a $95 \%$ confidence interval (Table 3). Movement distances ranged from $0.2 \mathrm{~km}$ to $11.4 \mathrm{~km}$. Average movement distance did not differ between sexes $(F=0.05, P=0.83)$, nor by duration of movement $(F=1.11, P=0.32)$.

\section{Discussion}

Knowledge of dispersal is important to the management of many species. The average juvenile dispersal distances that we report were similar to those reported in other studies of swift foxes $(\bar{x}=14.7 \mathrm{~km}$ in Kansas, Sovada et al. 2003; $\bar{x}=12.6 \mathrm{~km}$ in Colorado, Schauster 2001; $\bar{x}=12.1 \mathrm{~km}$ in Canada, Moehrenschlager 2000). Sovada et al. (2003) reported 3 juvenile foxes dispersing $\geq 20 \mathrm{~km}$ with $32 \mathrm{~km}$ being the greatest distance. We documented 9 foxes that dispersed $\geq 20 \mathrm{~km}$. Four were juveniles with the greatest dispersal distance being 
$63 \mathrm{~km}$; and 5 were adults with the greatest dispersal distance being $67 \mathrm{~km}$ (Table 2). Unlike Kamler et al. (2004), we did not have juvenile females that were philopatric to the natal home range. However, 6 juveniles ( 2 females, 4 males) stayed $\leq 5 \mathrm{~km}$ from their natal home range. No juveniles were found denning with the parents. Juvenile males tended to use the periphery of their natal home ranges. Timing of dispersal by juveniles was similar to that of Sovada et al. (2003) in Kansas, where peak dispersal occurred in October-November; however, dispersal timing in our study had a 2nd peak in January-February. Kilgore (1969) in Oklahoma and Covell (1992) in Colorado reported dispersal occurring earlier during August-September and September-October.

Transient foxes may be dispersing foxes that were displaying extraterritorial movements, because they moved into our study area and then out of our study area before settling down. Ultimately, we do not know whether these foxes moved onto our study site and then moved large distances off the study site.

The predominant direction of dispersal by swift foxes from PR was northwesterly. This direction was likely influenced by the presence of the town of Stratford located to the northeast and the predominance of cropland to the southeast and southwest (Fig. 1). We believe that the direction of dispersal in this study can be explained by swift fox avoidance of crop lands and areas with tall-structured vegetation such as Conservation Reserve Program (CRP) lands (Kamler 2002, Nicholson 2004). Nicholson et al. (2006) reported that swift foxes use short-structured vegetation more than would be expected.

Determining a justifiable distance for classifying specific movements as extraterritorial can be difficult. Foxes that moved $<2 \mathrm{~km}$ could have found the resources they were looking for without the need to move any farther. However, those movements could also be extreme outliers from the determined 95\% kernel home range. Average movement distance for all foxes was $6.3 \mathrm{~km}$, with 2 foxes exploring distances $\geq 11 \mathrm{~km}$ with return. We had evidence of mate swapping following bouts of extraterritorial movements by resident adults. Kitchen (2004) described extrapair copulation, breeding trios, and mate switching in Colorado. Our findings were similar in that the new mates taken by adult foxes were younger, and mate swapping occurred with neighboring foxes with prior short-term exploratory movements.

The dispersal distances we report suggest that swift fox subpopulations have a reasonable chance for interchange and may be better connected than previously thought. The dispersal pattern we observed suggests that swift foxes were capable of moving long distances using suitable grassland habitat to facilitate that movement. Dispersal, no matter what the distance, helps maintain genetic diversity within a population.

\section{ACKNOWLEDGMENTS}

We thank F. Pronger for allowing us to conduct the study on his land and for his enthusiasm and support of our work. We thank E. and B. Hampton for providing living accommodations and continual support for our work. We thank M. Butler, A. Pruett, C. Taylor, T. Thompson, A. McGee, and M. Tucker for their various amounts of support and volunteer time in the field. We thank employees of the USDA Forest Service office in Clayton, New Mexico, especially D. Garcia; and we thank D. Cook from Texas Parks and Wildlife for help and support. This study was funded by the National Fish and Wildlife Foundatation and Texas Tech University. The Texas Tech University Animal Care and Use Committee approved our capture methods. This is Texas Tech University, College of Agricultural Sciences and Natural Resources, technical publication T-9-1053.

\section{Literature Cited}

Ballard, W.B., L.A. Ayres, P.R. Krausman, D.J. Reed, and S.G. FANCY. 1997. Ecology of wolves in relation to a migratory caribou herd in northwest Alaska. Wildlife Monographs 135.

Brooker, L., M. Brooker, and P. Cale. 1999. Animal dispersal in fragmented habitat: measuring habitat connectivity, corridor use, and dispersal mortality. Conservation Ecology [online] 3(1):4. Accessed 20 September 2004. Available from: http://www.ecologyandsociety.org/voI3/issl/art4/.

CovelL, D.F. 1992. Ecology of the swift foxes (Vulpes velox) in southeastern Colorado. Master's thesis, University of Wisconsin-Madison, Madison.

DoOlan, S.P., AND D.W. MaCDonaLD. 1996. Dispersal and extra-territorial prospecting by slender-tailed meerkats (Suricata suricatta) on the south-western Kalahari. Journal of Zoology, London 240:59-73.

Hooge, P.N., W. Eichenlaub, And E. Solomon. 1999. The animal movement program. Alaska Biological Science Center. Accessed 14 October 2004. Available from: http://www.absc.usgs.gov/glba/gistools/index.htm 
Kamler, J.F., W.B. Ballard, E.M. Gese, R.L. Harrison, AND S.M. KarKI. 2004. Dispersal characteristics of swift foxes. Canadian Journal of Zoology 82:18371842.

Kamler, J.F., W.B. Ballard, R.L. Gilliland, and K. Mote. 2002. Improved trapping methods for swift foxes and sympatric coyotes. Wildlife Society Bulletin 30: 1262-1266.

KARKI, S.M. 2003. Effects of coyote removal on swift foxes (Vulpes velox) population ecology in southeastern Colorado. Master's thesis, Utah State University, Logan, UT.

KeITT, T.H., D.L. Urban, and B.T. MiLne. 1997. Detecting critical scales in fragmented landscapes. Conservation Ecology [online] 1:4. Accessed 20 September 2004. Available from: http://www.ecologyandsociety.orgivoll/issl/art4/.

Kilgore, D.L. 1969. An ecological study of the swift foxes (Vulpes velox) in the Oklahoma Panhandle. American Midland Naturalist 81:512-533.

Kitchen, A.M. 2004. Social and spatial ecology of the swift foxes (Vulpes velox) in southeastern Colorado. Master’s thesis, Utah State University, Logan.

Kitchen, A.M., E.M. Gese, and E.R. Schauster. 1999. Resource partitioning between coyotes and swift foxes: space, time, and diet. Canadian Journal of Zoology 77:1645-1656.

Koopman, M.E., B.L. Cypher, And J.H. Scrivner. 2000. Dispersal patterns of San Joaquin kit foxes (Vulpes macrotis mutica). Journal of Mammalogy 81:213-222.

Lidicker, W.Z., JR., And N.C. Stenseth. 1992. To disperse or not to disperse: who does it and why? Pages 21-33 in N.C. Stenseth and W.Z. Lidicker, Jr., editors, Animal dispersal: small mammals as a model. Chapman and Hall, London, U.K.

Moehrenschlager, A. 2000. Effects of ecological and human factors on the behavior and population dynamics of reintroduced Canadian swift foxes, (Vulpes velox). Doctoral dissertation, University of Oxford, Oxford, U.K.

NichoLSON, K.L. 2004. Swift fox use of black-tailed prairie dog towns in northwest Texas, with notes on movement. Master's thesis, Texas Tech University, Lubbock.

Nicholson, K.L., W.B. Ballard, B.K. McGeE, J. Surles, J.F. KAMLER, AND P.K. LEMONS. 2006. Swift fox use of black-tailed prairie dog towns in northwest Texas. Journal of Wildlife Management 70:1659-1666.

Schauster, E.R. 2001. Swift foxes (Vulpes velox) on the Pinon Canyon Maneuver Site, Colorado: population ecology and evaluation of survey methods. Master's thesis, Utah State University, Logan.

Sovada, M.A, C.C. Slivinski, R.O. WoOdWard, and M.L. Phillips. 2003. Home range, habitat use, litter size, and pup dispersal of swift foxes in two distinct landscapes of western Kansas. Pages 149-160 in M.A Sovada and L. Carbyn, editors, The swift foxes: ecology and conservation of swift foxes in a changing world. Canadian Plains Research Center, Regina, Saskatchewan, Canada.

Thomson, P.C., K. Rose, And N.E. KoK. 1992. The behavioural ecology of dingos in north western Australia. VI. Temporary extraterritorial movements and dispersal. Wildlife Research 19:585-595.

VAN BALLEnBERghe, V. 1983. Extraterritorial movements and dispersal of wolves in south central Alaska. Journal of Mammalogy 64:168-171.

White, G.C., And R.A. Garrott. 1990. Analysis of radiotracking data. Academic Press, Inc., San Diego, CA.

ZAR, J.H. 1999. Biostatistical analysis. 4th edition. Prentice Hall, Upper Saddle River, NJ.

Received 26 September 2005 Accepted 13 April 2006 